J. Clin. Chem. Clin. Biochem.

Vol. 27, 1989, pp. 413-418

(C) 1989 Walter de Gruyter \& Co.

Berlin · New York

\title{
Concentration of Zinc and Zinc-Copper Superoxide Dismutase Activity in Red Blood Cells in Normals and Children with Cancer
}

\author{
By Wojciech Wasowicz
}

Department of Biochemistry, Institute of Basic Sciences WAM, Eódź, Poland

Jerzy Kantorski

Department of Pathophysiology, Institute of Basic Sciences, WAM, Lódź, Poland

Danuta Perek

Department of Clinical Oncology, National Research Institute of Mother and Child, Warszawa, Poland

\section{Stefan Popadiuk}

Institute of Pediatrics, Medical Academy, Gdanisk, Poland

(Received October 5, 1988/March 6, 1989)

Summary: Zinc concentrations and $\mathrm{Cu}, \mathrm{Zn}$ superoxide dismutase activity in erythrocytes were investigated in 138 healthy children and in 35 children with cancer. The mean zinc concentration in the erythrocytes of healthy children was found to be age-dependent. In the youngest group (children up to 1 year of age) the zinc concentration in erythrocytes is $18.8 \pm 3.4 \mu \mathrm{g} / \mathrm{g} \mathrm{Hb}(5.89 \pm 1.23 \mathrm{mg} / \mathrm{l}$ packed cells), which is significantly lower than in other age groups. A strong logarithmic correlation $(r=0.327, p<0.0001$ and $r=0.436$, $\mathrm{p}<0.00001$ ) was found between age and zinc concentration in erythrocytes, expressed as $\mu \mathrm{g} / \mathrm{g} \mathrm{Hb}$ and as $\mathrm{mg} / \mathrm{l}$ packed red cells, respectively.

Cancer children were divided into two groups (neuro- and nephroblastoma). In the group of children with neuroblastoma no statistical differences in zinc concentration or enzyme activity were observed. In the patients with nephroblastoma, significantly higher zinc concentrations $(p<0.05)$ were observed in erythrocytes. The changes of zinc concentration are accompanied by significant $(p<0.02)$ decreases of enzyme activity. In this group of cancer children, statistically significant differences were observed in the zinc concentrations in erythrocytes $(\mu \mathrm{g} / \mathrm{g} \mathrm{Hb})$ between the second and the third stages of the disease. No correlation was observed between the concentration of zinc and enzyme activity in healthy children or in cancer children.

\section{Introduction}

Over the years, the importance of the role of zinc in the human organism has received considerable attention. In 1961, Prasad et al. (1), indicated for the first time that zinc deficiency may occur in humans. Clinical manifestations of zinc deficiency were described in the early sixties in subjects from the Middle East $(2,3)$; these were growth retardation, hypogonadism in males, poor appetite, mental lethargy and skin changes. These symptoms were abolished by zinc supplementation (4).

Most of the zinc in human blood (75-88\%) is found in the erythrocytes, where its concentration seems to be less variable than in plasma or serum (5). Zinc has been implicated in a large number of biological functions, most of them involving this element as an 
essential component of metalloenzymes (4). More than 200 zinc-containing enzymes are known to participate in many metabolic processes including nucleic acid, lipid and protein synthesis or degradation. The metal is present in several dehydrogenases, aldolases, peptidases, and phosphatases (4).

Ohno et al. (6), demonstrated that $92.4 \%$ of the total zinc content of erythrocytes is present in carbonic anhydrase $(87 \%)$ and $\mathrm{Zn}, \mathrm{Cu}$ containing superoxide dismutase $(5.4 \%)$.

Copper and zinc-containing superoxide dismutase (EC 1.15.1.1) catalyses the dismutation of superoxide anions to hydrogen peroxide, thus protecting the cell against superoxide radicals. In recent years, many publications have appeared on the subject of superoxide dismutase in malignant disease. However, the conclusions drawn have in general been based on few experimental observations, and those mainly on animal tumours $(7,8,9)$. Little is known about $\mathrm{Cu}, \mathrm{Zn}$ superoxide dismutase activity in the erythrocytes of cancer patients, and in cancer children in particular. Because abnormalities in zinc levels have been observed in association with certain malignancies (1014), we decided to make a comprehensive study of the zinc concentration and superoxide dismutase activity in erythrocytes of healthy children and those with cancer.

\section{Materials and Methods}

\section{Healthy children}

Zinc concentrations in erythrocytes were assayed in 138 healthy children aged 2 months -16 years ( 56 girls and 82 boys) from different parts of Poland, mainly from the central region. Superoxide dismutase activity in blood cells was determined in 112 children (46 girls and 66 boys). Venous blood samples for the investigation were taken from the cubital vein and placed in heparinized test tubes free from trace elements. The haematocrit and haemoglobin concentration (using Drabkin's reagent) were determined in the whole blood. The remaining blood was centrifuged for $5 \mathrm{~min}$ at $5000 \mathrm{~min}^{-1}$ to remove plasma and buffy coat. Erythrocytes were washed 3 times with $9 \mathrm{~g} / \mathrm{l} \mathrm{NaCl}$, then diluted with isotonic sodium chloride. The haematocrit and haemoglobin were determined in the resulting erythrocyte suspension, which was then stored at $-20^{\circ} \mathrm{C}$ until zinc analysis.

\section{Cancer children}

Zinc concentration and superoxide dismutase activity were determined in two groups of cancer children.

The first group consisted of 18 children ( 9 girls and 9 boys) with recognized neuroblastoma.

The second group included 17 children ( 5 girls and 12 boys) aged $1-6$ years, with nephroblastoma (tumour Wilmsi).

In the first group, 5 children ( 2 girls and 3 boys) were investigated at the time of diagnosis, while a further 13 children had already previously received chemo- and radiotherapy.
Five children with nephroblastoma ( 1 girl and 4 boys) were examined before their treatment began and 12 children ( 4 girls and 8 boys) were examined in the course of treatment with cytostatic pharmaceuticals or/and radiotherapy. The methods of drawing, preparation, and storage of samples for investigation were the same as for healthy children.

\section{Zinc determination}

is

The zinc concentration in the red blood cells of healthy as well as cancer children was determined by the method of Agarwal et al. (15), using a Beckman Model 1248 atomic absorption spectrophotometer with a deuterium background corrector.

Zinc concentrations in erythrocytes were expressed as $\mu \mathrm{g} / \mathrm{g} \mathrm{Hb}$ and $\mathrm{mg} / \mathrm{l}$ packed cells.

Lyophilized standard blood samples of the International Atomic Energy Agency (A-13) were used to monitor the accuracy of zinc analysis. The mean zinc content in these samples, calculated from ten successive series of determination, was 12.5 $\pm 0.97 \mu \mathrm{g} / \mathrm{g}$ dry weight. The reference zinc value for the standard was stated to be $13.0 \mu \mathrm{g} / \mathrm{g}$ dry weight with $95 \%$ confidence interval (16). The coefficient of variation was less than $10 \%$ for red blood cells $(n=8)$.

\section{Enzyme preparation and assay}

The red blood cell lysate was prepared as described by Minami \& Yoshikawa (17).

Haemoglobin was precipitated by vigorous shaking with chloroform : ethanol $(1+2$, by vol.) (18). After centrifugation, the clear supernatant was used for superoxide dismutase determination. Enzyme activity was measured by the spectrophotometric method (Pye Unicam SP-500 series 2 spectrophotometer) according to Misra \& Fridovich (19). The assay is based on the inhibition by superoxide dismutase of the superoxide radicalmediated conversion of adrenaline to adrenochrome in $\mathrm{pH}=10.2$ medium. The enzyme activity was calculated as arbitrary units per $\mathrm{mg}$ of haemoglobin.

The data obtained were used to calculate means, standard deviations, and correlation coefficient. Statistical significance was analysed by Student's t-test. Differences at $\mathrm{p}<0.05$ were considered significant.

\section{Results \\ Healthy children}

The results obtained in healthy children are presented in table 1 . The mean zinc concentration in erythrocytes of healthy children increased with the age of the child. In the group of children up to 1 year of age the concentration of zinc in erythrocytes was $18.8 \pm 3.4$ $\mu \mathrm{g} / \mathrm{g} \mathrm{Hb}(5.89 \pm 1.23 \mathrm{mg} / \mathrm{l}$ packed cells), which was significantly lower than in other age groups. From the 4 th to the 7 th year of age the concentration of zinc in erythrocytes was $34.9 \pm 6.7 \mu \mathrm{g} / \mathrm{g} \mathrm{Hb}$ (11.49 $\pm 2.52 \mathrm{mg} / 1$ packed cells) ( $p<0.001$ as compared with the youngest children). The erythrocyte zinc concentration of older children showed no further change, attaining a value of $33.4 \pm 8.24 \mu \mathrm{g} / \mathrm{g} \mathrm{Hb}$ at $8-16$ years of age. 
Tab. 1. Zinc concentration and superoxide dismutase activity in erythrocytes of healthy children.

\begin{tabular}{|c|c|c|c|c|}
\hline \multirow{2}{*}{$\begin{array}{l}\text { Age } \\
\text { (a) }\end{array}$} & \multirow[t]{2}{*}{$\mathbf{n}$} & \multirow{2}{*}{$\begin{array}{l}\mathrm{Cu}, \mathrm{Zn} \\
\text { superoxide } \\
\text { dismutase } \\
(\mathrm{U} / \mathrm{mg} \mathrm{Hb})\end{array}$} & \multicolumn{2}{|l|}{ Zinc } \\
\hline & & & $(\mu \mathrm{g} / \mathrm{g} \mathrm{Hb})$ & $\begin{array}{l}\text { (mg/l } \\
\text { packed cells) }\end{array}$ \\
\hline$<1$ & 12 & $3.51 \pm 0.34^{*}$ & $18.8 \pm 3.4^{*}$ & $5.89 \pm 1.23^{*}$ \\
\hline $1-3$ & 31 & $\begin{array}{l}3.60 \pm 0.52 \\
n=27 \\
\text { NS }\end{array}$ & $\begin{array}{l}28.2 \pm 9.0 \\
p<0.02^{* *}\end{array}$ & $\begin{array}{l}8.45 \pm 2.39 \\
p<0.02\end{array}$ \\
\hline $4-7$ & 33 & $\begin{array}{l}3.29 \pm 0.52 \\
n=13 \\
\text { NS }\end{array}$ & $\begin{array}{l}34.9 \pm 6.7 \\
p<0.001\end{array}$ & $\begin{array}{l}11.49 \pm 2.52 \\
p<0.001\end{array}$ \\
\hline$>7$ & 62 & $\begin{array}{l}3.49 \pm 0.53 \\
n=60 \\
N S\end{array}$ & $\begin{array}{l}33.4 \pm 8.2 \\
p<0.001\end{array}$ & $\begin{array}{l}10.88 \pm 2.56 \\
n=61 \\
p<0.001\end{array}$ \\
\hline
\end{tabular}

* Mean \pm standard deviation;

** Statistical significance was calculated in comparison with the youngest children.

NS Non-significant.

A positive statistically highly significant logarithmic correlation $(r=0.436, p<0.00001$, and $r=0.327$, $\mathrm{p}<0.0001$, fig. 1) was found between age and zinc concentration in erythrocytes, expressed as $\mathrm{mg} / \mathrm{l}$ packed erythrocytes, as $\mu \mathrm{g} / \mathrm{g} \mathrm{Hb}$, respectively.

Superoxide dismutase activity in children aged up to 1 year was $3.51 \pm 0.34 \mathrm{U} / \mathrm{mg} \mathrm{Hb}$ and this value remained unchanged up to the 16th year of age (tab. 1). No significant correlation was found between superoxide dismutase activity and zinc concentration in erythrocytes.
No sex-related differences in erythrocyte zinc concentration and superoxide dismutase activity were found.

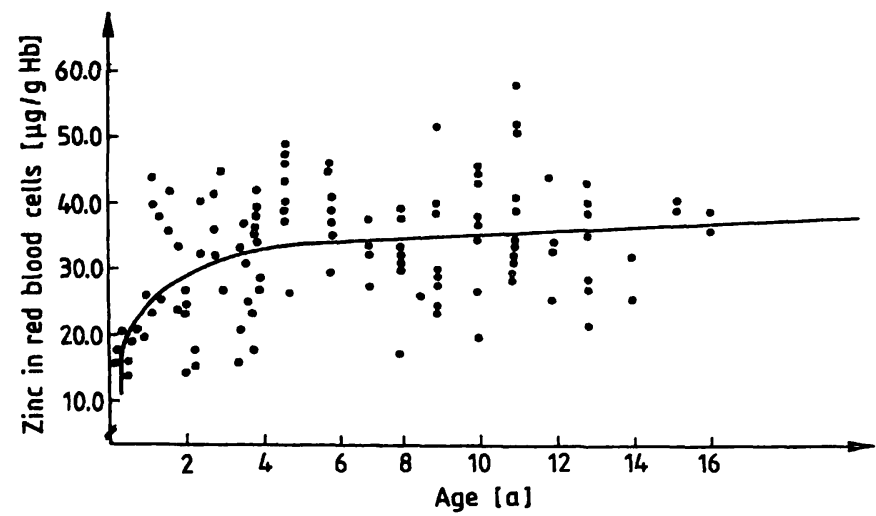

Fig. 1. Relationship between age and zinc concentration in erythrocytes of healthy children.

$y=26.41+3.26 \ln x$

$\mathrm{r}=0.327 ; \mathrm{p}<0.0001$

\section{Cancer children}

The results obtained in cancer children are presented in tables 2 and 3 . In the group of children with neuroblastoma no statistical differences in zinc concentration or the enzyme activity were observed as compared with the age-matched group of healthy children (tab. 2). No significant differences in the concentration of zinc and superoxide dismutase activity at different stages of the disease were observed (tab. 3). Differences in erythrocyte enzyme activity and zinc concentration between untreated children and children under treatment before the examination were not statistically significant.

Tab. 2 Zinc concentration and $\mathrm{Cu}, \mathrm{Zn}$ superoxide dismutase activity in erythrocytes and basic haematological parameters of cancer children. Mean \pm standard deviation are given.

\begin{tabular}{|c|c|c|c|c|}
\hline & $\begin{array}{l}\text { Neuroblastoma } \\
\mathrm{n}=18^{*}\end{array}$ & $\begin{array}{l}\text { Control } \\
\mathbf{n}=76\end{array}$ & $\begin{array}{l}\text { Tumour Wilmsi } \\
\mathrm{n}=17\end{array}$ & $\begin{array}{l}\text { Control } \\
\mathrm{n}=58\end{array}$ \\
\hline Age & 9 months -8 years & 9 months -8 years & $1-6$ years & $1-6$ years \\
\hline Haematocrit & $\begin{array}{l}0.324 \pm 0.058 \\
p<0.001 * *\end{array}$ & $0.372 \pm 0.026$ & $\begin{array}{l}0.336 \pm 0.046 \\
p<0.02\end{array}$ & $0.366 \pm 0.023$ \\
\hline $\begin{array}{l}\text { Haemoglobin } \\
\qquad(\mathrm{g} / \mathrm{l})\end{array}$ & $\begin{array}{l}104.6 \pm 23.5 \\
p<0.005\end{array}$ & $122.8 \pm 10.9$ & $\begin{array}{l}105.0 \pm 16.9 \\
\mathrm{p}<0.001\end{array}$ & $121.2 \pm 10.5$ \\
\hline $\begin{array}{l}\text { Plasma protein } \\
(\mathrm{g} / \mathrm{l})\end{array}$ & $\begin{array}{l}70.6 \pm 8.2 \\
\mathrm{NS}\end{array}$ & $71.6 \pm 4.1$ & $\begin{array}{l}68.7 \pm 7.8 \\
\text { NS }\end{array}$ & $71.2 \pm 4.2$ \\
\hline $\begin{array}{l}\text { Erythrocyte } \\
\text { superoxide dismutase } \\
\text { (U/mg Hb) }\end{array}$ & $\begin{array}{l}3.02 \pm 0.87 \\
\text { NS } \\
n=10\end{array}$ & $\begin{array}{l}3.45 \pm 0.51 \\
\mathrm{n}=52\end{array}$ & $\begin{array}{l}3.04 \pm 0.57 \\
p<0.02 \\
n=14\end{array}$ & $\begin{array}{l}3.52 \pm 0.52 \\
\mathrm{n}=31\end{array}$ \\
\hline $\begin{array}{l}\text { Erythrocyte } \mathrm{Zn} \\
(\mu \mathrm{g} / \mathrm{g} \mathrm{Hb})\end{array}$ & $\begin{array}{l}34.5 \pm 8.3 \\
\text { NS }\end{array}$ & $31.7 \pm 8.3$ & $\begin{array}{l}37.3 \pm 7.9 \\
p<0.05\end{array}$ & $32.1 \pm 8.9$ \\
\hline $\begin{array}{l}\text { Red blood cell Zin } \\
\text { (mg/l packed cells) }\end{array}$ & $\begin{array}{l}11.42 \pm 3.43 \\
\mathrm{NS}\end{array}$ & $9.99 \pm 2.84$ & $\begin{array}{l}12.13 \pm 2.66 \\
p<0.02\end{array}$ & $10.18 \pm 2.93$ \\
\hline
\end{tabular}

* Number of subjects

** Significant difference in comparison with age-matched group of healthy children NS Non-significant 
Tab. 3. Malignant stage and zinc concentration and $\mathrm{Cu}, \mathrm{Zn}$ superoxide dismutase activity in erythrocytes of cancer children. Mean \pm standard deviation are given.

\begin{tabular}{|c|c|c|c|}
\hline Malignant stage & I-II & III & IV \\
\hline \multicolumn{4}{|l|}{ Neuroblastoma } \\
\hline $\begin{array}{l}\text { Superoxide dismutase } \\
\text { (U/mg Hb) }\end{array}$ & $\begin{array}{l}3.72 \\
\mathrm{n}=1^{*}\end{array}$ & $\begin{array}{l}2.75 \pm 0.99 \\
\mathrm{NS} \\
\mathrm{n}=4\end{array}$ & $\begin{array}{l}3.09 \pm 0.88 \\
\mathrm{NS} \\
\mathrm{n}=\dot{5}^{\prime}\end{array}$ \\
\hline $\begin{array}{l}\mathrm{Zn} \\
\quad(\mu \mathrm{g} / \mathrm{g} \mathrm{Hb})\end{array}$ & $\begin{array}{l}29.9 \pm 12.7 \\
n=3\end{array}$ & $\begin{array}{l}37.9 \pm 7.3 \\
\text { NS } \\
n=7\end{array}$ & $\begin{array}{l}33.3 \pm 7.3 \\
N S \\
n \equiv 8\end{array}$ \\
\hline $\begin{array}{l}\mathrm{Zn} \\
\quad(\mathrm{mg} / \mathrm{l} \text { packed cells) }\end{array}$ & $\begin{array}{l}11.0 \pm 6.1 \\
\mathrm{n}=3\end{array}$ & $\begin{array}{l}11.7 \pm 2.6 \\
\mathrm{NS} \\
\mathrm{n}=7\end{array}$ & $\begin{array}{l}11.3 \pm 3.5 \\
N S \\
n=8\end{array}$ \\
\hline Malignant stage & II & III & $\mathrm{IV}-\mathrm{V}$ \\
\hline \multicolumn{4}{|l|}{ Tumour Wilmsi } \\
\hline $\begin{array}{l}\text { Superoxide dismutase } \\
\text { (U/mg Hb) }\end{array}$ & $\begin{array}{l}2.88 \pm 0.59 \\
n=5\end{array}$ & $\begin{array}{l}3.00 \pm 0.42 \\
\mathrm{NS} \\
\mathrm{n}=7\end{array}$ & $\begin{array}{l}3.50 \\
\mathrm{NS} \\
\mathrm{n}=2\end{array}$ \\
\hline $\begin{array}{l}\mathrm{Zn} \\
\quad(\mu \mathrm{g} / \mathrm{g} \mathrm{Hb})\end{array}$ & $\begin{array}{l}33.8 \pm 3.4 \\
\mathrm{n}=7\end{array}$ & $\begin{array}{l}41.7 \pm 8.6 \\
\mathrm{p}<0.05^{* *} \\
\mathrm{n}=7\end{array}$ & $\begin{array}{l}35.2 \pm 10.9 \\
N S \\
n=3\end{array}$ \\
\hline $\begin{array}{l}\mathrm{Zn} \\
\quad(\mathrm{mg} / \mathrm{l} \text { packed cells) }\end{array}$ & $\begin{array}{l}10.92 \pm 2.30 \\
n=7\end{array}$ & $\begin{array}{l}13.36 \pm 2.76 \\
\mathrm{NS} \\
\mathrm{n}=7\end{array}$ & $\begin{array}{l}12.02 \pm 2.79 \\
\mathrm{NS} \\
\mathrm{n}=3\end{array}$ \\
\hline
\end{tabular}

* Number of subjects

** Statistically significant difference in comparison with $\mathrm{II}^{\text {nd }}$ stage of disease

NS non-significant

In the patients with tumour Wilmsi the measured concentration of zinc in erythrocytes was significantly higher than in the healthy age-matched group (tab. $2)$. The difference amounted to $16.3 \%(p<0.005)$ $(\mu \mathrm{g} / \mathrm{g} \mathrm{Hb})$, and $19.1 \%(\mathrm{mg} / 1$ packed erythrocytes). The changes of zinc concentration are accompanied by significantly lowered superoxide dismutase activity (13.6\%; p < 0.02) (tab. 2).

In the children with tumour Wilmsi a statistically significant difference $(p<0.05)$ was observed in the zinc concentration in erythrocytes $(\mu \mathrm{g} / \mathrm{g} \mathrm{Hb})$ between the second and the third stages of the disease (tab. 3). No significant differences in the concentration of zinc or the activity of the enzyme were observed between treated and untreated nephroblastoma patients.

\section{Discussion}

The zinc concentration in human red blood cells is approximately 14 times higher than in plasma (20). Measurements of zinc in erythrocytes may therefore be useful as an indication of long-term zinc status, since these cells have an average life-span of 120 days.
The data of Hinks et al. (21) demonstrate that approximately $90 \%$ of the blood zinc is associated with the erythrocytes, while the plasma contains $9 \%$ of the total blood zinc. Linderman et al. (22) determined the zinc concentration in erythrocytes of men and women aged 20-89 years, and found a positive linear correlation between age and zinc concentration. Other authors confirm the linear correlation between the age of the examined subjects and zinc concentration both in plasma (23) and in whole blood (5).

Contrary to the work quoted above, our results indicate a logarithmic correlation between the age of the examined children and the concentration of zinc in erythrocytes. In our opinion, a logarithmic curve describes more accurately the differences in zinc concentration in the erythrocytes of children up to the third year of age, as well as the plateau observed at about 5-7 years (tab. 1, fig. 1). In agreement with Linderman et all. (22), we found no statistically significant sex differences in the mean erythrocyte zinc concentrations. Our investigation did not reveal any age-dependent changes in the erythrocyte superoxide dismutase activity of healthy children (tab. 1). Other authors $(24-26)$ have reported similar conclusions. 
Special interest has been focused on the role of zinc in patients with malignant diseases $(11,23,27-29)$. Few reports, however, deal with changes in the concentration of zinc in erythrocytes, while none of the available literature is addressed to the determination of zinc in the erythrocytes of children with neoplastic disease.

In the present investigation, statistically significant increases in the zinc concentration of erythrocytes were accompanied by simultaneous decreases in superoxide dismutase activity in children with nephroblastoma. A similar but non-significant tendency was observed in the group of children with neuroblastoma. In the latter group the increase of zinc in erythrocytes amounted to $9 \%$ (14.3\% per packed erythrocytes), whereas the enzyme activity was lowered by $9 \%$ (tab. 2). In plasma, zinc concentrations are usually low in cancer patients $(11,23,27,29)$. Some investigators associate the lowered concentration of the element in plasma with an increased demand of the neoplastic tissue for zinc (30). Aldor et al. (10) demonstrated a decrease of zinc concentration in plasma, whole blood and erythrocytes in patients with different forms of neoplastic disease. The decrease was significant in plasma and whole blood and non-significant in erythrocytes.

The increased concentration of zinc in the erythrocytes of the examined children is difficult to interpret. It is possibly due to ineffective erythropoiesis, in that the erythrocyte precursor normoblasts do not divide and mature normally. A similarly high erythrocyte zinc concentration is present in other clinical conditions associated with ineffective erythropoiesis (31). The reports on superoxide dismutase activity in neoplastic disease are not comprehensive and, as already mentioned, based upon examination of neoplastic tissue in animals. So far, there have been few reports on superoxide dismutase activity in human erythrocytes and in normal and pathological human cell lines. Saito et al. (32) demonstrated that superoxide dismutase activity in the erythrocytes of stomach cancer patients was not significantly different from that of normal subjects. Moreover, Marklund et al. (33) found no essential differences in the activity of the enzyme between normal and neoplastic cell lines. In our investigation, the observed activity of the erythrocyte enzyme was lowered by $9 \%$ in the case of neuroblastoma and by $13.7 \%$ in the case of nephroblastoma. Since a molecule of superoxide dismutase contains atoms of two metals, copper and zinc (34), the activity of the enzyme should depend on their concentration. However, Vilas et al. (35) did not find a relation between the concentrations of copper and zinc and superoxide dismutase activity, either in umbilical cord blood or in the blood of neonates. In the blood of rats, on the other hand, a lowered superoxide dismutase activity was observed as a result of copper deficiency (36). Copper is a part of the catalytic site of superoxide dismutase, so its deficiency may influence the activity of the enzyme, while zinc is a structural element of enzymatic protein and in extreme cases can be replaced by other cations (37). Hence, even considerable fluctuations in the concentration of zinc in the tissues may not cause changes in superoxide dismutase activity.

In our opinion, not only the changes of zinc concentration in the blood of children with neoplastic disease, but also the concentration of copper should be taken into consideration. In addition, the ratio of copper to zinc, regarded as a specific marker of neoplastic disease $(11,23,27,28)$, should be calculated. The concentration of other elements, antagonistic to zinc should also be measured, e.g. the concentration of selenium whose role in neoplastic processes has recently been widely discussed (38). Examination of the activity of not only superoxide dismutase, but also of catalase and glutathione peroxidase may provide answers to many questions related to this problem. Such investigations are now in progress.

\section{Acknowledgement}

This work was supported in part by the Institute of Oncology, Warszawa. Grant No 11.5. The skillful technical assistance of Ms Krystyna Różycka and Mrs Grażyna Michalska is gratefully acknowledged.

\section{References}

1. Prasad, A. S., Halsted, J. A. \& Nadimi, M. (1961) Syndrome of iron deficiency anemia hepatosplenomegaly, hypogonadism, dwarfism and geophagia. A.m. J. Med. 31, $532-546$

2. Prasad, A. S. (1966) Metabolism of zinc and its deficiency in human subjects. In: Zinc metabolism (Prasad, A. S., ed.), Springfield, Illinois: CC Thomas, pp. 250-303.
3. Prasad, A. S., Miale, A., Farid, Z., Schultert, A. \& Sandstead, H. H. (1963) Zinc metabolism in patients with the syndrome of iron deficiency anemia, hypogonadism and dwarfism. J. Lab. Clin. Med. 61, 537-549.

4. Prasad, A. S. (1985) Clinical and biochemical manifestation zinc deficiency in human subjects. J. Pharmacol. 16, 344352. 
5. Buxaderas, S. C. \& Farre-Rovira, R. (1985) Whole blood and serum zinc levels in relation to sex and age. Rev. Espan. Fisiol. 41, 463-470.

6. Ohno, H., Doi, R., Yamamura, K., Yamashita, K., Izuka, S. \& Naniguchi, N. (1985) A study of zinc distribution in erythrocytes of normal humans. Blut 50, 113-116.

7. Bize, J. B., Oberley, L. W. \& Morris, H. P. (1980) Superoxide dismutase and superoxide radical in the Morris hepatomas. Cancer Res. 40, 3686-3693.

8. Oberley, L. W., Bize, J. B., Sahn, S. K., Chan Leuthanser, S. W. H. \& Gruber, H. E. (1978) Superoxide dismutase activity of normal murine liver, regenerating liver and $\mathrm{H} 6$ hepatoma. J. Natl. Cancer Inst. 61, 375-379.

9. Sahu, S. K., Oberley, L. W., Stevens, R. H. \& Riley, E. E. (1977) Superoxide dismutase of Ehrlich ascites tumor cells. J. Natl. Cancer Inst. 58, 1125-1128.

10. Aldor, Y., Walach, N., Modai, D. \& Horn, Y. (1982) Zinc and copper levels in plasma, erythrocytes, and whole blood in cancer patients. Klin. Wochenschr. 60, 375-377.

11. Brandes, J. M., Lightman, A., Drugan, A., Zinder, O., Cohen, A. \& Itskovitz, J. (1983) The diagnostic value of serum copper/zinc ratio in gynecological tumors. Acta Obstet. Gynecol. Scand. 62, 225-229.

12. Horicko, J. \& Pantucek, M. (1983) Hypozincemia in patients with malignant melanoma. Clin. Chim. Acta 130, $279-282$.

13. Lipman, T. O., Diamond, A., Mellow, M. H. \& Patterson, K. Y. (1987) Esophageal zinc content in human squamous esophageal cancer. J. Am. Coll. Nutr. 6, 41-46.

14. Mellow, M. H., Layne, E. A., Lipman, T. O., Kaushik, M., Hostetler, C. \& Smith, J. C. (1983) Plasma zinc and vitamin $A$ in human squamous carcinoma of the esophagus. Cancer $51,1615-1620$.

15. Agarwal, R. P. \& Henkin, R. I. (1985) A simple method for simultaneous estimation of zinc and copper in erythrocytes. Biol. Trace. Elem. Res. 7, 199-208.

16. Muramatsu, Y. \& Parr, R. M. (1985) Surrey of currently available reference materials for use in connection with the determination of trace elements in biological and environmental materials. International Atomic Energy Agency (RL/128).

17. Minami, M. \& Yoshikawa, I. (1979) A simplified assay method of superoxide dismutase activity for clinical use. Clin. Chim. Acta 92, 337-342.

18. McCord, J. M. \& Fridovich, I. (1969) The utility of superoxide dismutase in studying free radical reactions. J. Biol. Chem. 244, 6056-6063.

19. Misra, H. P. \& Fridovich, I. (1972) The role of superoxide anion in the autooxidation of epinephrine and a simple assay for superoxide dismutase. J. Biol. Chem. 247, 31703175.

20. Prasad, A. S. (1985) Laboratory diagnosis of zinc deficiency. J. Am. Coll. Nutr. 4, 591-598.

21. Hinks, L. J., Clayton, B. E. \& Lloyd, R. S. (1983) Zinc and copper concentration in leukocytes and erythrocytes in healthy adults, and the effect of oral contraceptives. J. Clin. Pathol. 36, 1016-1021.

22. Linderman, R. D., Clark, M. L. \& Colmore, J. P. (1971) Influence of age and sex on plasma and red-cell zinc concentrations. J. Gerontol. 25, 358-363.

23. Lightman, A., Brandes, J. M., Binur, N., Drugan, A. \& Zinder, O. (1986) Use of the serum copper/zinc ratio in the differential diagnosis of ovarian malignancy. Clin. Chem. $32,101-103$.
24. Joenje, H., Frents, R. R., Arvet, F. \& Eriksson, A. W. (1978) Specific activity of human erythrocyte superoxide dismutase as a function of donor age. Mech. Aging. Dev. 8, 265-267.

25. Jóźwiak, Z. \& Jasnowska, B. (1985) Changes in oxygenmetabolizing enzymes and lipid peroxidation in human erythrocytes as a function of age of donor. Mech. Aging. Dev. 32, 77-83.

26. Maral, J., Puget, K. \& Michelson, A. M. (1977) Comparative study of superoxide dismutase, catalase and glutathione peroxidase levels in different animals. Biochem. Biophys. Res. Commun. 77, 1525-1535.

27. Breiter, D. N., Diasio, R. B., Neifeld, J. P., Roush, M. L. \& Rosenberg, S. A. (1978) Serum copper and zinc measurement in patients with osteogenic sarcoma. Cancer 42, $598-602$.

28. Fisher, G. L., Byers, V. S., Shifrine, M. \& Levin, A. S. (1976) Copper and zinc levels in serum from human patients with sarcomas. Cancer 37, 356-363.

29. Inutsuka, S. \& Araki, S. (1978) Plasma copper and zinc levels in patients with malignant tumors of digestive organs. Cancer 42, 626-631.

30. Abdulla, M., Dasthi, H. M. \& Mathur, A. (1987) The role of zinc and copper in neoplasia. In: Elements in health and disease (Said, H. M., ed.). Hamdard Foundation Press, Pakistan, pp. 197-205.

31. Mahajan, S. K., Prasad, A. S., Rabbami, P., Briggs, W. A. \& McDonald, F. D. (1979) Zinc metabolism in uremia. J. Lab. Clin. Med. 94, 693-698.

32. Saito, K., Saito, T., Kurita, T., Kobayashi, M. \& Ito, T. (1987) Blood and tissue trace elements and destiny of superoxide anions in patients with stomach cancer. In: Trace elements in human health and disease. Extended abstracts. Second Nordic Symposium. Odense 17-21 August 1987, pp. $177-180$.

33. Marklund, S. L., Westman, N. G., Lundgren, E. \& Roos, G. (1982) Copper- and zinc-containing superoxide dismutase manganese containing superoxide dismutase catalase and glutathione peroxidase in normal and neoplastic human cell lines and normal human tissues. Cancer Res. 42, 1955-1961.

34. McCord, J. M. \& Fridovich, I. (1969) Superoxide dismutase: An enzymic function for erythrocuprein (hemocuprein). J. Biol. Chem. 244, 6049-6055.

35. Vilas, N. N., Vidyasagar, S., Kohrs, M. B., Martin, S. E., Olson, R. \& Kamath, S. K. (1986) Copper, zinc and superoxide dismutase levels in cord blood. Nutr. Res. 6, 327331.

36. Mylroire, A. A., Collins, H., Umbles, C. \& Kyle, J. (1986) Erythrocyte superoxide dismutase activity and other parameters of copper status in rats ingesting lead acetate. Toxicol. Appl. Pharmacol. 82, 512 $=520$.

37. Paynter, D. I., Moir, R. J. \& Underwood, E. J. (1979) Changes in activity of the $\mathrm{Cu}-\mathrm{Zn}$ superoxide dismutase enzymes in tissues of the rat with changes in dietary copper. J. Nutr. 109, 1570-1576.

38. Schrauzer, G. N. (1987) Trace elements in cancer diagnosis and therapy. A review. In: Trace element analytical chemistry in medicine and biology, Vol 4 (Brätter, P. \& Schramel, P., eds.), Walter de Gruyter \& Co., Berlin, New. York, pp. 403-417.

Wojciech Wąsowicz Ph. D.

Department of Biochemistry INP WAM

Medical Academy

pl. 9-Maja 1

PL-90=647 Łódź 